\title{
Energy and protein nutritional requirements for Nellore bulls ${ }^{1}$
}

\author{
Luiz Fernando Costa e Silva ${ }^{2}$, Sebastião de Campos Valadares Filho ${ }^{3}$, Diego Zanetti ${ }^{4}$, \\ Polyana Pizzi Rotta ${ }^{2}$, Marcos Inácio Marcondes ${ }^{5}$, Laura Franco Prados ${ }^{2}$, Mário Fonseca \\ Paulino ${ }^{5}$, Henrique de Oliveira Azevedo 4
}

\footnotetext{
${ }^{1}$ Partially financed by Fapemig and INCT de Ciência Animal.

${ }^{2}$ Mestrando em Zootecnia, DZO-UFV.

${ }^{3}$ Departamento de Zootecnia - UFV. Coordinator of INCT de Ciência Animal.

${ }^{4}$ Granduando em Zootecnia - UFV. Scholar from IC of INCT de Ciência Animal.

${ }^{5}$ Departamento de Zootecnia - UFV. Member of INCT de Ciência Animal.
}

\begin{abstract}
The objective of this study was to determine the nutritional requirements of energy and protein and estimate the efficiencies of metabolizable energy utilization for fat and protein deposition, as well as for maintenance $\left(\mathrm{k}_{\mathrm{m}}\right)$ and growth $\left(\mathrm{k}_{\mathrm{g}}\right)$. An experiment of comparative slaughter was carried out with thirty-seven 14-month-old ( \pm 1 month) Nellore bulls with $259 \pm 24.9 \mathrm{~kg}$. Animals were divided as follows: five to reference, four to maintenance level and twentyeight bulls feeding ad libitum. Bulls were also grouped in 4 different feedlot periods (42, 84, 126 and 168 days) for slaughter. The diet was composed of corn silage and concentrate, at a 55:45 ratio. After the slaughter, the left half carcasses were totally dissected for determination of body composition. The energy requirements for maintenance were obtained by exponentially relating the heat production and the metabolizable energy intake, while the energy requirements for gain $\left(\mathrm{NE}_{\mathrm{g}}\right)$ were obtained according to empty body weight (EBW) and EBW gain (EBG). The net protein requirements for gain $\left(\mathrm{NP}_{\mathrm{g}}\right)$ were estimated according to EBG and retained energy $(\mathrm{RE})$. The net $\left(\mathrm{NE}_{\mathrm{m}}\right)$ and metabolizable $\left(\mathrm{ME}_{\mathrm{m}}\right)$ energy requirements for maintenance were 76.5 and $113.84 \mathrm{kcal} / \mathrm{EBW}^{0.75} /$ day, respectively. The $\mathrm{k}_{\mathrm{m}}$ was 0.67 . The equations for $\mathrm{NE}_{\mathrm{g}}$ and $\mathrm{NP}_{\mathrm{g}}$ were: $\mathrm{NE}_{\mathrm{g}}(\mathrm{Mcal} / \mathrm{day})=$ $0.0555 \times \mathrm{EBW}^{0.75} \times \mathrm{EBG}^{1.095}$ and $\mathrm{NP}_{\mathrm{g}}(\mathrm{g} /$ day $)=263.37 \times \mathrm{EBG}-23.21 \times \mathrm{RE}$. The $\mathrm{k}_{\mathrm{g}}$ was 0.33 . The efficiencies to deposition of energy as protein and fat were 0.18 and 0.71 , respectively. The model obtained for the percentage of retained energy as protein $\left(\% \mathrm{RE}_{\mathrm{p}}\right)$ was $\% \mathrm{RE}_{\mathrm{p}}=2.4221 \times(\mathrm{RE} / \mathrm{EBG})^{-1.6472}$. The net and metabolizable energy requirements for maintenance of Nellore bulls were 76.5 and $113.84 \mathrm{kcal} / \mathrm{EBW}^{0.75} / \mathrm{day}$. The energy and protein requirements for gain could be obtained by the respective equations: $\mathrm{NE}_{\mathrm{g}}(\mathrm{Mcal} /$ day $)=0.0555 \times \mathrm{EBW}^{0.75} \times \mathrm{EBG}^{1.095}$ and $\mathrm{NP}_{\mathrm{g}}(\mathrm{g} /$ day $)=263.37 \times \mathrm{EBG}-23.21 \times \mathrm{RE}$.
\end{abstract}

Key Words: deposition, efficiency, growth, maintenance, metabolizable energy

\section{Introduction}

The global scientific research on animal nutrition has tried to define the nutrients required by the animals, for more than a century (Preston, 2006). Knowing the concentration of the amount of nutrients in the diet that each animal category requires to achieve the desired performance, along with knowledge of the nutritional value of the feedstuffs available, allows us to efficiently, technically and economically formulate diets, plan and implement the nutritional management of the herd (Valadares Filho \& Chizzotti, 2011).

In Brazil, the balancing of diets designed to beef cattle has been done according to the nutritional requirements recommended by international committees (AFRC, 1993; NRC, 2000; among others) due to the relative shortage of national data. Valadares Filho et al. (2006) published the first Brazilian charts of nutritional requirements of Zebu cattle. However, they were formulated from a relatively small database.

Valadares Filho et al. (2010) published the Brazilian Tables of Nutritional Requirements of Zebu Beef Cattle (BR-CORTE, 2nd edition), using a database with experiments conducted in Brazilian conditions in the last two decades. Nevertheless, the majority of the animals on the database utilized were in the finishing phase (Chizzotti et al., 2007; Marcondes et al., 2009; Souza et al., 2009).

The estimate of efficiency of energy utilization for maintenance and weight gain is important, for they are affected by several factors such as age, composition or condition of feed (Blaxter et al., 1966; Garrett, 1980; Gionbelli, 2010). However, these pieces of information, on Nellore with lower weights, are scarce.

Therefore, the objective of this study was to estimate the nutritional requirements of energy and protein, the use efficiencies of metabolizable energy for maintenance and 
gain and the efficiency of deposition of energy in the forms of protein and fat of non-castrated Nellore cattle.

\section{Material and Methods}

The experiment was conducted in the experimental feedlot from the Animal Science Department (DZO) of Universidade Federal de Viçosa (UFV), in Viçosa, MG, Brazil.

Of a total of 37 Nellore bulls with initial average body weight of $259 \pm 24.90 \mathrm{~kg}$ and average age of 14 months, five animals composed the reference group, four were fed at maintenance level (1.1\% of its body weight) and 28 animals were kept under feeding ad libitum.

Animals were randomly divided in four groups (seven fed ad libitum and one from the maintenance group), which were slaughtered at different feedlot times (42, 84, 126 and 168 days). Four replicates per treatment (sixteen animals) were kept under Tie Stall system, with automatic drinker and concrete trough, fed individually. Another three replicates per treatment (twelve animals) and animals at maintenance were kept in collective stalls with concrete floor, provided with individual feeder (electronic gates), with a total area of $50 \mathrm{~m}^{2}$, with $8 \mathrm{~m}^{2}$ covered with corrugated zinc sheets and collective concrete drinker.

The diet was formulated according to recommendations of Valadares Filho et al. (2010). The diet consisted of $550 \mathrm{~g} / \mathrm{kg}$ dry matter (DM) of corn silage and $450 \mathrm{~g} / \mathrm{kg} \mathrm{DM}$ concentrate formulated based on ground corn, soybean meal, urea/ammonium sulfate, limestone, salt and mineral mix (Tables 1 and 2).

Feed was supplied twice daily and adjusted daily so that leftovers were kept around 5 to $10 \%$ of the total supplied, with water permanently available to the animals. The amount of diet supplied was recorded daily; samples of each concentrate, corn silage and leftovers of each animal were collected daily as well.

Samples were grouped proportionally, at each sevenday period, thus becoming composite samples, which were
Table 2 - Proportions of ingredients in concentrate and diet and concentrate and bromatological composition of concentrate and diet on a dry matter (DM) basis

\begin{tabular}{|c|c|c|}
\hline \multirow[t]{2}{*}{ Ingredients } & Concentrate & Diet \\
\hline & \multicolumn{2}{|c|}{ Proportion (g/kg DM) } \\
\hline Corn silage & - & 550.0 \\
\hline Corn & 816.4 & 367.4 \\
\hline Soybean meal & 136.9 & 61.6 \\
\hline Mineral mix & 9.9 & 4.4 \\
\hline Limestone & 6.8 & 3.0 \\
\hline Salt & 10.0 & 4.5 \\
\hline Urea & 18.0 & 8.1 \\
\hline \multirow[t]{2}{*}{ Ammonium sulfate } & 2.0 & 0.9 \\
\hline & \multicolumn{2}{|c|}{ Chemical composition (g/kg DM) } \\
\hline Dry matter & 875.8 & 554.9 \\
\hline Organic matter & 946.5 & 944.7 \\
\hline Crude protein & 194.9 & 123.4 \\
\hline Ether extract & 30.1 & 26.2 \\
\hline Neutral detergent fiber ${ }^{1}$ & 134.3 & 347.0 \\
\hline Non-fiber carbohydrates & 615.8 & 460.9 \\
\hline
\end{tabular}

dried in forced-ventilation oven $\left(60^{\circ} \mathrm{C}\right)$ and ground in $1 \mathrm{~mm}$ mesh sieve. At the end of each period, a composite sample of leftovers was obtained by period of 42 days, proportionally to the dry matter of the leftovers of each week. For the silage, composite sample was made of each period of 21 days, proportionally to the dry matter of each week, for further laboratory analyses.

The ingredients that composed the concentrate were sampled directly from the silos of the ration factory every time they were mixed. Due to the long experimental period, composite samples were made for each experimental period, proportionally to the amount of each mix of the diet.

Initially, all the animals were weighed, identified and treated against endo and ectoparasites. After an adaptation period of 30 days, in which all the animals received the same diet, reference animals were slaughtered to estimate initial body composition and empty body weight (EBW) of the remaining animals. Weighting was performed at every 42 days for determination of weight gain. The experimental

Table 1 - Chemical composition of feeds used in experimental diets

\begin{tabular}{|c|c|c|c|c|c|c|}
\hline \multirow[t]{2}{*}{ Ingredient } & \multirow{2}{*}{$\begin{array}{l}\mathrm{DM} \\
\mathrm{g} / \mathrm{kg}\end{array}$} & $\mathrm{OM}$ & $\mathrm{CP}$ & $\mathrm{EE}$ & NDFap & NFC \\
\hline & & \multicolumn{5}{|c|}{$\mathrm{g} / \mathrm{kg} \mathrm{DM}$} \\
\hline Corn silage & 292.3 & 943.2 & 64.9 & 23.0 & 521.1 & 334.2 \\
\hline Corn & 869.9 & 977.3 & 85.8 & 34.6 & 143.1 & 713.8 \\
\hline Urea & 978.4 & 983.9 & 2884.1 & - & - & - \\
\hline Ammonium sulfate & 985.8 & 965.5 & 1313.6 & - & - & - \\
\hline Mineral mix & 963.6 & 93.3 & 3.7 & - & - & - \\
\hline
\end{tabular}

DM - dry matter; OM - organic matter; CP - crude protein; EE - ether extract; NDFap - neutral detergent fiber corrected for ash and protein; NFC - non-fiber carbohydrates. 
period lasted 198 days (30 days for adaptation and four periods of 42 days), with three intermediate slaughter sessions and one at the end.

Before slaughter, animals were subjected to solid fasting for 16 hours. The slaughter was performed via stunning and jugular cutting for total bleeding, followed by washing of the gastrointestinal tract (rumen, reticulum, omasum, abomasum and small and large intestines). Weights of heart, lungs, liver, spleen, kidneys, internal fat, industrial meat, mesentery, tail and trimmings, along with those from the washed gastrointestinal tract were added to the other body parts (carcass, head, hides, paws and blood), for determination of EBW.

The average ratio obtained between EBW and body weight (BW) of reference animals was utilized for the estimate of initial EBW of the animals which remained in the experiment.

At each slaughter, samples of head and an anterior and a posterior limb of animals at maintenance and two from the animals feeding ad libitum were taken. Constituents were weighed separately; the soft tissue was ground, bones were sawn and both were sampled for further laboratory analyses. The hide was added to the hide removed from the body of the animal.

After slaughter, the carcass of each animal was divided in two half-carcasses, which were weighed and then chilled in cold chamber ( $4^{\circ} \mathrm{C} / 18$ hours). After this time, left halfcarcasses were weighed and a sample was taken from the section between the 9th and 11th ribs, according to recommendations of Hankins \& Howe (1946), for further dissection and prediction of proportions of muscle, fat tissue and bones in the carcass.

After removal of the sample corresponding to the section between the 9th and 11th rib cut, left half-carcasses were dissected into bones, fat and muscles; muscle and fat were ground separately, and, right after, a composite sample proportional to the amount present in the carcass was made. Bones were divided in long bones, vertebrae and ribs. They were sampled, sawn, and a composite sample of the bones in the carcass, also proportional to the corresponding weigh in the carcass, was made. For the quantification of the compositions of muscle, fat and bones of the half-carcass, the amounts obtained at the section of the 9th and 11th rib cut and those obtained at the complete dissection of the half-carcasses were summed.

Rumen, reticulum, omasum, abomasum, small and fat intestines, internal fat, mesentery, liver, heart, kidneys, lung, tongue, spleen, industrial meet and trimmings (esophagus, trachea and reproductive system) were ground in industrial cutter for 20 minutes, for constitution of a homogeneous sample of organs and viscera.

With the exception of blood, the samples of organs and viscera, muscle and fat, bones of the carcass, hides, soft tissues of the paws, soft tissue of the head, bones of the paws and bones of the head were conditioned in aluminum recipients and lyophilized for evaluation of fat in dry matter (FDM). After, samples were defatted from successive washing with petroleum ether in Soxhlet-type extractors, for evaluation of partially defatted dry matter (PDDM). Next, they were ground in ball-type mill, for further laboratory analyses.

Samples of corn silage, concentrate ingredients, leftovers, feces and all the samples of each animal component were quantified as for the content of dry matter (DM), mineral matter (MM), total nitrogen and ether extract (EE), according to Silva \& Queiroz (2002). Crude protein (CP) was obtained by the product between the total nitrogen and the 6.25 factor. The fat extracted at the partial defatting was calculated by the difference between FDM and PDDM, whose result was added to those obtained for the residual ether extract on PDDM, for evaluation of the total fat content.

The neutral detergent fiber (NDF) content was obtained according to Van Soest et al. (1991). At the analyses of soybean meal, sodium sulfite was added (Undersanter et al., 1993), in order to reduce the retention of protein content. The Ankom ${ }^{\circledR}$ system was utilized for evaluations of NDF, by adding thermostable $\alpha$-amylase. Nonwoven fabric $\left(100 \mathrm{~g} / \mathrm{m}^{2}\right)$ was utilized for the extractions. The NDF content was corrected for ashes and protein in all samples $\left(\mathrm{NDF}_{\mathrm{ap}}\right)$.

Non-fibrous carbohydrates (NFC) were calculated as proposed by Detmann \& Valadares Filho (2010), in which $\mathrm{NFC}=100-\left[(\% \mathrm{CP}-\% \mathrm{CP}\right.$ from urea $+\%$ urea $)+\% \mathrm{NDF}_{\text {ap }}$ $+\% \mathrm{EE}+\% \mathrm{MM}]$. The total digestible nutrients (TDN) were obtained according to recommendations from the NRC (2001). The TDN content was estimated by the relation between the intake of TDN and DM. The digestible energy (DE) was obtained by the digestible nutrients multiplied by their respective energy values, as described by the NRC (2001), whereas concentration of metabolizable energy (ME) was considered 82\% of the DE (Coelho da Silva \& Leão, 1979).

Body fat and protein contents were determined in function of their percentage concentrations in the organs, viscera, hide, blood, head, paws and carcass samples (bones, muscle and fat).

The determination of body energy was obtained from the body contents of protein and fat and their respective 
caloric equivalents, according to equation recommended by the ARC (1980):

$\mathrm{EC}=5.6405 \mathrm{X}+9.3929 \mathrm{Y}$,

in which EC = energy content $(\mathrm{Mcal}), \mathrm{X}=\operatorname{body} \operatorname{protein}(\mathrm{kg})$ and $\mathrm{Y}=$ body fat $(\mathrm{kg})$.

For the conversion of BW into EBW, the relations between EBW and BW of animals kept in the experiment were calculated. For the conversion of empty body weight gain (EBG) into average daily gain (ADG), the relations between them were calculated then utilized for conversion of the requirements for EBG into requirements for ADG.

Contents of energy and protein in the body in function of EBW were estimated by means of allometric equations of the body contents of energy and protein of the animals at performance, maintenance and reference according to the following model:

$\mathrm{C}_{\mathrm{i}}=\mathrm{a} \times \mathrm{EBW}^{\mathrm{b}}$,

in which $\mathrm{C}_{\mathrm{i}}=$ "i $\mathrm{i}$ " constituent of the animal body, which can be energy (Mcal) or protein (kg); EBW = empty body weight; and "a" and "b" = regression parameters.

From the regression parameters presented above, the net requirements of energy and protein per kg of empty body weight gain can be calculated by the derivative of the equation above, following the model below:

$\mathrm{Y}=\mathrm{a} \times \mathrm{b} \times \mathrm{EBW}^{\mathrm{b}-1}$,

where $Y=$ net energy requirement for gain $(\mathrm{Mcal} / \mathrm{EBG})$ or net requirement of protein for gain (g/EBG).

A regression equation was adjusted between retained energy (RE) and daily EBW gain, for certain metabolic EBW $\left(\mathrm{kg}^{0.75}\right)$, for the animals at maintenance and performance, utilizing the following model:

$\mathrm{RE}=\mathrm{a} \times \mathrm{EBW}^{0.75} \times \mathrm{EBG}^{\mathrm{b}}$,

where $\mathrm{RE}=$ retained energy $\left(\mathrm{Mcal} / \mathrm{EBW}^{0.75} /\right.$ day $) ; \mathrm{EBW}^{0.75}=$ metabolic empty body weight $\left(\mathrm{kg}^{0.75}\right)$; and $\mathrm{EBG}=$ empty body weight gain (kg/day).

The proportion of energy retained in the form of protein $\left(\mathrm{RE}_{\mathrm{p}}\right)$ was estimated according to the model suggested by Marcondes et al. (2010):

$\mathrm{RE}_{\mathrm{p}}=\beta_{0} \times\left(\frac{\mathrm{RE}}{\mathrm{ERG}}\right)^{\beta_{1}}$,

where $\mathrm{RE}_{\mathrm{p}}=$ percentage of energy retained in the form of protein; $\mathrm{RE}=$ retained energy $(\mathrm{Mcal} /$ day $) ; \mathrm{EBG}=$ empty body weight gain ( $\mathrm{kg} /$ day); and $\beta_{0}$ and $\beta_{1}$ are regression parameters.

Some authors (Tedeschi et al., 2002; Tedeschi et al., 2004; Chizzotti et al., 2008) suggested that in order to estimate the energy requirements for maintenance, the exponential method is the most suitable. Thus, the net energy requirement for maintenance (Mcal/EBW ${ }^{0.75} / \mathrm{day}$ ) was calculated from the intercept $\left(\beta_{0}\right)$ of the exponential regression between HP and MEI. The model utilized was the following:

$\mathrm{HP}=\beta_{0} \times \mathrm{e}^{(\beta 1 \times \mathrm{MEI})}$,

where $\mathrm{HP}=$ heat production $\left(\mathrm{Mcal} / \mathrm{EBW}^{0.75} / \mathrm{day}\right)$; MEI = metabolizable energy intake $\left(\mathrm{Mcal} / \mathrm{EBW}^{0.75} /\right.$ day $)$; and $\beta_{0}$ and $\beta_{1}$ are regression parameters and ' $\mathrm{e}$ ' is the Euler number(3.718281).

The requirement of metabolizable energy for maintenance $\left(\mathrm{ME}_{\mathrm{m}}, \mathrm{Mcal} / \mathrm{EBW}^{0.75} / \mathrm{day}\right)$ was determined by the iterative method, and $\mathrm{ME}_{\mathrm{m}}$ was considered the $\mathrm{MEI}$ value at the moment MEI equals HP.

The efficiency of the requirement of metabolizable energy for maintenance $\left(\mathrm{k}_{\mathrm{m}}\right)$ was obtained from the ratio between the net and metabolizable energy for maintenance requirements obtained by the models evaluated.

For the calculation of partial use efficiencies of metabolizable energy for the fat and protein synthesis, the following equation was adjusted:

$\mathrm{MEI}=\mathrm{ME}_{\mathrm{m}}+\beta_{1} \times \Delta_{\text {prot }}+\beta_{2} \times \Delta_{\text {fat }}$,

where MEI is the total daily intake of metabolizable energy (Mcal/EBW ${ }^{0.75}$ ); $\Delta_{\text {prot }}$ and $\Delta_{\text {fat }}$ are variations of body energy in function of the protein and fat $\left(\mathrm{Mcal} / \mathrm{EBW}^{0.75}\right)$, respectively; and $\beta_{1}$ and $\beta_{2}$ are multiple regression coefficients. The inverse of coefficients $\beta_{1}$ and $\beta_{2}$ stand for the efficiencies of deposition of energy in the form of protein and fat ( $\mathrm{k}_{\text {prot }}$ and $\mathrm{k}_{\mathrm{fat}}$ ), respectively.

For the calculation of net requirements of protein for weight gain, the model involving EBG and concentration of energy in the gain was adjusted; animals from performance and maintenance groups were utilized:

$\mathrm{RP}=\beta_{1} \times \mathrm{EBG}+\beta_{2} \times \mathrm{RE}$,

where $\mathrm{RP}=$ retained protein (g/day); EBG = empty body weight gain (kg/day); RE = retained energy (Mcal/day); and $\beta_{1}$ and $\beta_{2}$ are regression parameters.

The requirement of metabolizable protein for maintenance $\left(\mathrm{MP}_{\mathrm{m}}\right)$ suggested by Valadares Filho et al. (2010) was considered, where $\mathrm{MP}_{\mathrm{m}}=4.0 \times \mathrm{BW}^{0.75}$, while the requirement of metabolizable protein for gain $\left(\mathrm{MP}_{\mathrm{g}}\right)$ was calculated, dividing the net requirements of protein for gain by the utilization efficiency of metabolizable protein for gain $(\mathrm{k})$, according to equation proposed by Valadares Filho et al. (2010).

The data were analyzed as non-linear models built by the feature NLIN of SAS (Statistical Analysis System, version 9.2), adjusted by the Gauss-Newton method. For all the tests, 0.05 was utilized as critical level of probability to verify the significance of parameters of the models. 


\section{Results and Discussion}

The average ratio between EBW and HP was 0.914 superior to those reported by BR-CORTE (Valadares Filho et al., 2010) and the NRC (2000), which were 0.895 and 0.891 , respectively. This ratio can vary from 0.85 to 0.95 (NRC, 2000). In the present study, the utilization of young animals caused greater participation of the gastrointestinal tract in relation to the total weight.

For the conversion of requirements for empty body weight gain (EBG) into requirements of average body weight daily gain (ADG), the average ratio between EBWG and ADG was 1.013, which was very close to the 1.014 of noncastrated Nellore finishing cattle (Marcondes et al., 2007) and 8.6 and 7.2\% higher than those obtained by Valadares Filho et al. (2010) and the NRC (2000), who and which presented EBWG/ADG ratios of 0.936 and 0.951 , respectively.

Relating heat production (HP) with metabolizable energy intake (MEI), the following equation was obtained: $\mathrm{HP}=0.0765 \times \mathrm{e}^{(3.4915 \times \mathrm{MEI})}$, where $\mathrm{HP}=$ heat production $\left(\mathrm{Mcal} / \mathrm{EBW}^{0.75} / \mathrm{day}\right)$; and $\mathrm{MEI}=$ metabolizable energy intake (Mcal/EBW ${ }^{0.75} /$ day).

The value of net energy for maintenance $\left(\mathrm{NE}_{\mathrm{m}}\right)$ obtained for non-castrated Nellore males was $76.5 \mathrm{kcal} / \mathrm{EBW}^{0.75} /$ day. Valadares Filho et al. (2010) suggested 74.2 kcal/EBW $0.75 /$ day. Chizzotti et al. (2008), in a study involving analysis of data from 389 pure breed Nellore animals or crossbred Nellore with taurine breeds, estimated maintenance requirement of $75 \mathrm{kcal} / \mathrm{EBW}^{0.75} / \mathrm{day}$. The value obtained is close to that of the basal metabolic rate suggested for warm-blooded adult mammals, when measured in respirometric chamber, of $69 \mathrm{kcal} / \mathrm{EBW}^{0.75} /$ day (Poczopko, 1971).

The requirements of metabolizable energy for maintenance $\left(\mathrm{ME}_{\mathrm{m}}\right)$ were $113.84 \mathrm{kcal} / \mathrm{EBW}^{0.75} /$ day, which is a value obtained when HP equals MEI. This value is $3.46 \%$ inferior to that suggested by Valadares Filho et al. (2010) and $1.70 \%$ superior to that suggested by Chizzotti et al. (2008), who utilized the same calculation method.

The equation obtained for the body content of energy in function of EBW was EC $=0.0727 \pm 0.0193 \times \mathrm{EBW}^{1.6084}$ \pm 0.0440 , where EC = energy content, in Mcal; and EBW = empty body weight, in $\mathrm{kg}$.

As EBW increases, the concentration of energy in the animal due to the raise in body fat also does. The net energy requirement $\left(R E_{g}\right)$ per kg of EBW gain can be calculated from the derivative of the equation: $\mathrm{RE}_{\mathrm{g}}=$ $0.1169 \times \mathrm{EBW}^{0.6084}$, where $\mathrm{RE}_{\mathrm{g}}$ is the requirement of net energy for gain (Mcal/kg EBG); and EBW is the empty body weight (kg).
To estimate the requirements of energy for any weight range of weight gain, the following equation was obtained: $\mathrm{NE}_{\mathrm{g}}=0.0555 \times \mathrm{EBW}^{0.75} \times \mathrm{EBG}^{1.095}$, where $\mathrm{NE}_{\mathrm{g}}$ is the requirement of net energy for gain (Mcal/day) and EBG is the empty body weight gain ( $\mathrm{kg} / \mathrm{day})$. The equation obtained is similar to that suggested for bulls, whose value of 0.0533 cited by the authors is very close to the 0.0555 obtained at this experiment (Valadares Filho et al., 2010).

The main nutritional requirement systems (AFRC, 1993; NRC, 2000; CSIRO, 2007) separate the utilization efficiency of the metabolizable energy in utilization efficiency for maintenance $\left(\mathrm{k}_{\mathrm{m}}\right)$ and utilization efficiency of the energy for gain $\left(\mathrm{k}_{\mathrm{g}}\right)$.

When dividing $\mathrm{NE}_{\mathrm{m}}$ by $\mathrm{ME}_{\mathrm{m}}$, we have the $\mathrm{k}_{\mathrm{m}}$ value of 0.67 . The $\mathrm{k}_{\mathrm{m}}$ values reported by Valadares Filho et al. (2006) and Chizzotti et al. (2008) were 0.63 and 0.67 , respectively. These values are similar to that obtained at this study. Several factors can affect $\mathrm{k}_{\mathrm{m}}$, such as the level of dietary fiber, the level of metabolizable energy intake, the proportion of fatty acids absorbed and the protein turnover (Garrett, 1980). Like CSIRO (2007), states reports that factors such as gender, breed, age and environment affect $\mathrm{k}_{\mathrm{m}}$, Marcondes et al. (2010) studied the effect of diverse factors on $\mathrm{k}_{\mathrm{m}}$ and concluded that the partial use efficiency of metabolizable energy for gain $\left(\mathrm{k}_{\mathrm{g}}\right)$ and empty body weight gain (EBWG) affect $\mathrm{k}_{\mathrm{m}}$. This implies that the maintenance requirements are affected by the performance of the animals. The model suggested for Zebu animals by Marcondes et al. (2010) was $\mathrm{k}_{\mathrm{m}}=0.513+0.173 \times \mathrm{k}_{\mathrm{g}}+0.100 \times$ EBG, where $\mathrm{k}_{\mathrm{m}}$ is the utilization efficiency of metabolizable energy for maintenance; $\mathrm{k}_{\mathrm{g}}$ is the utilization efficiency of metabolizable energy for gain; and EBG is the empty body weight gain in $\mathrm{kg} /$ day .

Utilizing this equation, the mean value obtained for this experiment would be 0.70 . This value is close to that obtained by the division of $\mathrm{NE}_{\mathrm{m}}$ by $\mathrm{ME}_{\mathrm{m}}$. However, the utilization of a variable $\mathrm{k}_{\mathrm{m}}$ becomes important, for when feedstuffs of low digestibility are utilized, the ME presents problems to estimate $\mathrm{k}_{\mathrm{m}}$ (Johnson et al., 1977).

In order to convert the net energy requirements into requirements of metabolizable energy for gain, the knowledge of the utilization efficiency of metabolizable energy for weight gain $\left(\mathrm{k}_{\mathrm{g}}\right)$ becomes necessary. This efficiency can be estimated as the slope coefficient of the RE regression in function of the MEI (Valadares Filho et al., 2010) (Figure 1).

Gionbelli (2010), working with growing Nellore females, utilized the same procedure and obtained a $\mathrm{k}_{\mathrm{g}}$ value of 0.38 . This value is close to that found at this experiment, which was 0.33 . One might suggest that the utilization efficiency 


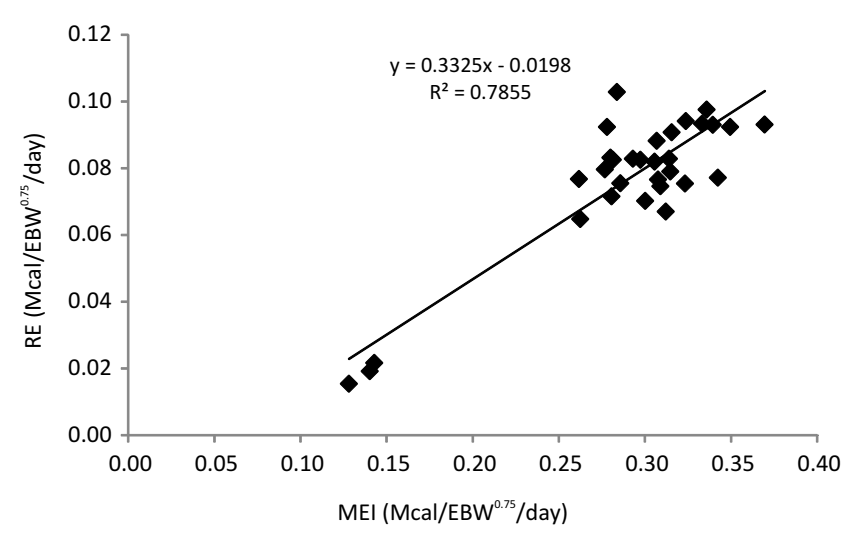

Figure 1 - Retained energy (RE) in function of metabolizable energy intake (MEI).

of the metabolizable energy for gain was very close, regardless of the gender.

In most of the studies carried out in Brazil, static values for $\mathrm{k}_{\mathrm{g}}$ have been estimated. However, the efficiency with which energy is retained in the body $\left(\mathrm{k}_{\mathrm{g}}\right)$ depends on the proportions of energy taken in the form of protein and fat. Since fat deposition efficiency is superior to that of protein and the proportions of protein and fat are variable, there is the necessity to obtain a $\mathrm{k}_{\mathrm{g}}$ that is also variable.

For the calculation of partial use efficiencies of metabolizable energy for the synthesis of fat and protein, the following equation was obtained: $\mathrm{MEI}=113.84+5.56 \times$ $\Delta_{\text {prot }}+1.41 \times \Delta_{\text {fat }}$, in which MEI is the daily metabolizable energy intake (Mcal/ $\mathrm{EBW}^{0.75}$ ); and $\Delta_{\text {prot }}$ and $\Delta_{\text {fat }}$ are the variations of body energy in function of protein and fat (Mcal/EBW ${ }^{0.75}$ ).

From this model, the deposition efficiencies of energy in the form of fat $\left(\mathrm{k}_{\mathrm{f}}\right)$ and protein $\left(\mathrm{k}_{\mathrm{p}}\right)$ were calculated. Thus, $\mathrm{k}_{\mathrm{f}}$ was equal to 0.71 and $\mathrm{k}_{\mathrm{p}}$ was equal to 0.18 . Chizzotti et al. (2008) achieved $0.79 \mathrm{k}_{\mathrm{f}}$ and $0.34 \mathrm{k}_{\mathrm{p}}$, from the analysis of 16 experiments with 369 animals, whereas Gionbelli (2010) obtained $0.83 \mathrm{k}_{\mathrm{f}}$ and $0.25 \mathrm{k}_{\mathrm{p}}$. CSIRO (2007), however, adopts $\mathrm{k}_{\mathrm{f}}$ and $\mathrm{k}_{\mathrm{p}}$ values of 0.75 and 0.45 , respectively.

The proportion of energy retained in the form of protein $\left(\mathrm{RE}_{\mathrm{p}}\right)$ was estimated according to the potential model suggested by Marcondes et al. (2010). The model obtained was $R_{p}=2.4221 \times(R E / E B G)^{-1.6472}$, where $R E_{p}$ is the energy retained in the form of protein; $\mathrm{RE}$ is the retained energy, in Mcal/day; and EBG is the empty body weight gain, in $\mathrm{kg} / \mathrm{day}$. The $\mathrm{RE}_{\mathrm{p}}$ can be utilized in the conversion of net energy into metabolizable energy for being directly correlated with the utilization efficiency of metabolizable energy for gain (Willians \& Jenkins, 2003; Tedeschi, 2004). Marcondes et al. (2010) utilized a database of 752 animals raised in Brazilian conditions and did not observe differences between genders or between Nellore and crossbred animals for $\mathrm{RE}_{\mathrm{p}}$, which was equal to $1.140 \times(\mathrm{RE} / \mathrm{EBG})^{-1.137}$.

Marcondes et al. (2010) suggested the calculation of $\mathrm{k}_{\mathrm{g}}$ in function of the $\mathrm{RE}_{\mathrm{p}}$ utilizing the equation $\mathrm{k}_{\mathrm{g}}=0.327 /[0.539$ $\left.+\left(\% \mathrm{RE}_{\mathrm{p}} / 100\right)\right]$. Therefore, the utilization of this model, which takes a variable $\mathrm{k}_{\mathrm{g}}$ into consideration, seems to have more applicability, once there is the combination of efficiency with the gain composition.

The equation obtained to describe the body crude protein content (CPC) in function of the increase in EBW was $\mathrm{CPC}=0.2142 \pm 0.0314 \times \mathrm{EBW}^{0.9477 \pm 0.0246}$, where CPC is the body content of crude protein, in $\mathrm{kg}$, and EBW is the empty body weight, in $\mathrm{kg}$.

The net requirements of protein for one kg of empty body weight gain (RP) were estimated from the following equation: $\mathrm{RP}=0.2030 \times \mathrm{EBW}^{-0.0523}$, in which $\mathrm{RP}$ is the net energy of protein for gain, expressed in grams per kg EBG.

As EBW increases, there is a decrement in RP, represented by the negative exponent linked to EBW, resulting in lower protein gain per kg EBG. With the increase in weight, there is decrease in muscle tissue deposition and increase in the deposition of fat tissue into the body reserves.

The net requirements of protein $\left(\mathrm{NP}_{\mathrm{g}}\right)$ for any weight gain range were estimated from the model involving EBG and the concentration of energy in the gain: $\mathrm{NP}_{\mathrm{g}}=263.37 \times$ EBG $-23.21 \times \mathrm{RE}$, in which, $\mathrm{NP}_{\mathrm{g}}$ is the net requirement of protein, in g/day; EBG is the empty body weight gain, in $\mathrm{kg} / \mathrm{day}$; and RE is the retained energy, in Mcal/day. Values close to the parameters obtained in this experiment were found in Nellore females at growth $(\mathrm{RP}=256.0 \times \mathrm{EBG}-25.71$ $\times$ RE) (Gionbelli, 2010). Other authors have recommended the equation $\mathrm{RP}=238.79 \times \mathrm{EBG}-15.68 \times \mathrm{RE}$ to estimate the net requirements of protein. However, one must be aware that the database utilized by BR-CORTE (Valadares Filho et al., 2010) contains most of the data originated from finishing animals. As one can see by the parameter attributed to EBG, bulls, for having greater growth potential, present higher $\mathrm{NP}_{\mathrm{g}}$ (Valadares Filho et al., 2010). Comparing the equation obtained in this study with that described by Gionbelli (2010), higher coefficient could be observed for EBG in the equation described in the present study. Thus, it is clear that the circulating testosterone may be contributing to the greater deposition of lean tissue in bulls.

The utilization efficiency of metabolizable protein for gain (k) was calculated according to the suggestion of Valadares Filho et al. (2010), where: $\mathrm{k}(\%)=84.665-(0.1179$ $\times \mathrm{EBW}_{\mathrm{eq}}$ ) for animals with body weight at fasting lower or equal to $350 \mathrm{~kg}$ and a fixed value of 0.469 for animals above this weight. 
From the generated equations above, the nutritional requirements of energy and protein for Nellore bulls of various body weights were estimated (Table 3 ).

The requirements of net energy for gain ( $\left.\mathrm{NE}_{\mathrm{g}}, \mathrm{Mcal} / \mathrm{day}\right)$, total requirements (maintenance and weight gain) of metabolizable energy (ME, Mcal/day), total requirements (maintenance and weight gain) of total digestible nutrients (TDN, kg/day) of purebred non-castrated Nellore cattle of different weights and weight gain rates were estimated from the equations generated in this experiment (Table 4).

Considering an animal weighting $400 \mathrm{~kg}$ of body weight and with $1 \mathrm{~kg}$ of ADG:

- $\mathrm{BW}=0.9143 \times \mathrm{SBW}=400 \times 0.9143=365.72 \mathrm{~kg}$

$-\mathrm{EBG}=1,013 \times \mathrm{ADG}=1.013 \times 1=1.013 \mathrm{~kg}$

$-\mathrm{NE}_{\mathrm{g}}=0.0555 \times \mathrm{EBW}^{0.95} \times \mathrm{EBG}^{1.095}=0.0555 \times 365.72^{0.75}$ $\times 1.013^{1.095}=4.71 \mathrm{Mcal} /$ day

$-\mathrm{NE}_{\mathrm{m}}=76.5 \mathrm{kcal} / \mathrm{EBW}^{0.75} / \mathrm{day}=76.5 \times 365.72^{0.75}=$ $6.40 \mathrm{Mcal} /$ day

- $\mathrm{ME}_{\mathrm{m}}=\mathrm{NE}_{\mathrm{m}} / \mathrm{k}_{\mathrm{m}}=6.40 / 0.6749=9.52 \mathrm{Mcal} / \mathrm{day}$

$-\mathrm{RE}_{\mathrm{p}}=2.4221 \times(\mathrm{RE} / \mathrm{EBG})^{-1.6472}=2.4221 \times(4.71 / 1.013)^{-}$ $1.6472=0.1928$

- $\mathrm{k}_{\mathrm{g}}=0.327 /\left[0.539+\left(\% \mathrm{RE}_{\mathrm{p}} / 100\right)\right]=0.327 /[0.539+$ $(19.28 / 100)]=0.4468$

$-\mathrm{ME}_{\mathrm{g}}=\mathrm{NE}_{\mathrm{g}} / \mathrm{k}_{\mathrm{g}}=4.71 / 0.4468=10.54 \mathrm{Mcal} /$ day

$-\mathrm{ME}_{\text {total }}=\mathrm{ME}_{\mathrm{m}}+\mathrm{ME}_{\mathrm{g}}=9.48+10.54=20.06 \mathrm{Mcal} / \mathrm{day}$
- $\mathrm{DE}=\mathrm{ME} / 0.82=20.06 / 0.82=24.41 \mathrm{Mcal} /$ day

- $\mathrm{TDN}=\mathrm{DE} / 4.409=24.41 / 4.409=5.55 \mathrm{Mcal} / \mathrm{day}$

Likewise, the net requirements of protein for gain $\left(\mathrm{NP}_{\mathrm{g}}\right.$, g/day), total requirements (maintenance and gain) of metabolizable protein (MP, g/day), rumen degradable protein requirements (RDP, g/day), rumen undegradable protein requirements (RUP, g/day) and crude protein requirements (CP, g/day) were estimated for Nellore bulls (Table 5).

Considering the same animal with $400 \mathrm{~kg}$ of body weight and with $1 \mathrm{~kg}$ of ADG:

$-\mathrm{EBW}_{\mathrm{eq}}=(\mathrm{EBW} \times 430) / 440=(365.72 \times 430) / 440=$ $357.41 \mathrm{~kg}$

$-\mathrm{NP}_{\mathrm{g}}=263.37 \times \mathrm{EBG}-23.21 \times \mathrm{RE}=263.37 \times 1.013-23.21$ $\times 4.71=157.52 \mathrm{~g}$

$-\mathrm{k}=0.469$

- $\mathrm{MP}_{\mathrm{m}}=4.0 \times \mathrm{PC}^{0.75}=4 \times 400^{0.75}=357.77 \mathrm{~g}$

$-\mathrm{MP}_{\mathrm{g}}=\mathrm{NP}_{\mathrm{g}} / \mathrm{k}=157.47 / 0.469=335.86 \mathrm{~g}$

$-\mathrm{MP}_{\text {total }}=\mathrm{MP}_{\mathrm{m}}+\mathrm{MP}_{\mathrm{g}}=357.77+335.86=693.63 \mathrm{~g}$

- $\mathrm{CP}_{\text {mic }}=120 \times \mathrm{TDN}=120 \times 5.54=665.66 \mathrm{~g}$

$-\mathrm{RDP}=\mathrm{CP}_{\text {mic }} \times 1.11=666.00 \times 1.11=738.89 \mathrm{~g}$

$-\mathrm{RUP}=\left[\mathrm{MP}_{\text {total }}-\left(\mathrm{CP}_{\mathrm{mic}} \times 0.64\right)\right] / 0.8=[693.63-(665.66$ $\times 0.64)] / 0.8=334.51 \mathrm{~g}$

- $\mathrm{CP}=\mathrm{RDP}+\mathrm{RUP}=738.89+334.51=1.073 .39 \mathrm{~g}$

Considering an animal with $1 \mathrm{~kg}$ ADG, as its body weight increases, there is augmentation in the requirements

Table 3 - Abstract of estimative models of nutritional requirements of energy and protein for Nellore bulls

\begin{tabular}{|c|c|c|}
\hline Item & Equation & Unit \\
\hline EBW & $0.9143 \times \mathrm{SBW}$ & $\mathrm{kg}$ \\
\hline $\mathrm{EBW}_{\mathrm{eq}}$ & $(\mathrm{EBW} \times 430) / 440$ & $\mathrm{~kg}$ \\
\hline EBG & $1.013 \times \mathrm{ADG}$ & kg/day \\
\hline $\mathrm{NE}_{\mathrm{m}}$ & 76.5 & $\mathrm{kcal} / \mathrm{EBW}^{0.75} / \mathrm{day}$ \\
\hline $\mathrm{ME}_{\mathrm{m}}$ & 113.84 & kcal/EBW $0.75 /$ day \\
\hline $\mathrm{k}_{\mathrm{m}}$ & 0.6720 & - \\
\hline $\mathrm{NE}_{\mathrm{g}}$ & $0.0555 \times \mathrm{EBW}^{0.75} \times \mathrm{EBG}^{1.095}$ & Mcal/day \\
\hline$R E_{p}^{5}$ & $2.4221 \times(\mathrm{RE} / \mathrm{EBG})^{-1.6472}$ & - \\
\hline $\mathrm{k}_{\mathrm{g}}{ }^{\mathrm{P}}$ & $0.327 /\left[0.539+\left(\% \mathrm{RE}_{\mathrm{p}} / 100\right)\right]$ & - \\
\hline $\mathrm{ME}_{\mathrm{g}}$ & $\mathrm{NE}_{\mathrm{g}} / \mathrm{k}_{\mathrm{g}}$ & Mcal/day \\
\hline $\mathrm{ME}^{\circ}$ & $\mathrm{ME}_{\mathrm{m}}+\stackrel{\mathrm{M} \mathrm{E}_{\mathrm{g}}}{ }$ & Mcal/day \\
\hline $\mathrm{DE}$ & $\mathrm{ME} \times 0.82^{\circ}$ & kcal/EBW $0.75 /$ day \\
\hline TDN & $\mathrm{DE} \times 4.409$ & kg/day \\
\hline $\mathrm{NP}_{\mathrm{g}}$ & $\mathrm{NP}_{\mathrm{g}}=263.37 \times \mathrm{EBG}-23.21 \times \mathrm{RE}$ & g/day \\
\hline $\mathrm{k}$ & $\begin{array}{c}\mathrm{BW} \leq 350 \mathrm{~kg}, \mathrm{k}(\%)=84.665-0.1179 \times \mathrm{EBW}_{\mathrm{eq}} \\
\mathrm{BW}>350 \mathrm{~kg}, \mathrm{k}=0.469\end{array}$ & - \\
\hline $\mathrm{MP}_{\mathrm{g}}$ & $\mathrm{NP}_{\mathrm{g}} / \mathrm{k}$ & g/day \\
\hline $\mathrm{MP}_{\mathrm{m}}^{\mathrm{s}}$ & $4 \times \mathrm{BW}^{0.75}$ & g/day \\
\hline $\mathrm{MP}_{\text {total }}$ & $\mathrm{MP}_{\mathrm{m}}+\mathrm{MP}_{\mathrm{g}}$ & g/day \\
\hline $\mathrm{CP}_{\text {mic }}$ & $\mathrm{CP}_{\text {mic }}=120 \times \mathrm{TDN}$ & g/day \\
\hline RDP & $\left(\mathrm{CP}_{\text {mic }} \times 1.11\right)$ & g/day \\
\hline RUP & $\left(\mathrm{MP}_{\text {total }}-\left(\mathrm{CP}_{\text {mic }} \times 0.64\right)\right) / 0.8$ & g/day \\
\hline $\mathrm{CP}$ & RDP + RUP & g/day \\
\hline
\end{tabular}

EBW - empty body weight; SBW - inserir legendas; EBW = equivalent empty body weight; EBG - empty body weight gain; ADG - average daily gain; NE - net energy for maintenance; $\mathrm{ME}_{\mathrm{m}}$ - metabolizable energy for maintanance; $\mathrm{k}_{\mathrm{m}}$ - efficiency of the requirement of metabolizable energy for maintenance; $\mathrm{NE}_{\mathrm{g}}$ - net energy for gain; $\mathrm{RE}_{\mathrm{p}}$ - energy retained in the form of protein; $\mathrm{k}_{\mathrm{g}}$ - use efficiency of metabolizable energy for gain; $\mathrm{ME}_{\mathrm{g}}$ - metabolizable energy for gain; ME - metabolizable energy; DE - digestible energy; $\mathrm{TDN}$ - total digestible nutrients; $\mathrm{NP}_{\mathrm{g}}$ - net protein requirements for gain; $\mathrm{k}$ - utilization efficiency of metabolizable protein for gain; $\mathrm{MP}$ - metabolizable protein for gain; $\mathrm{MP}_{\mathrm{m}}$ - metabolizable protein for maintenance; $\mathrm{MP}_{\text {total }}$ - total metabolizable protein; $\mathrm{CP}_{\text {mic }}$ - microbial crude protein; RDP - rumen degradable protein; RUP - rumen undegradable protein; CP - crude protein. 
Table 4 - Energy requirements of Nellore bulls of different body weight, for any weight gain range

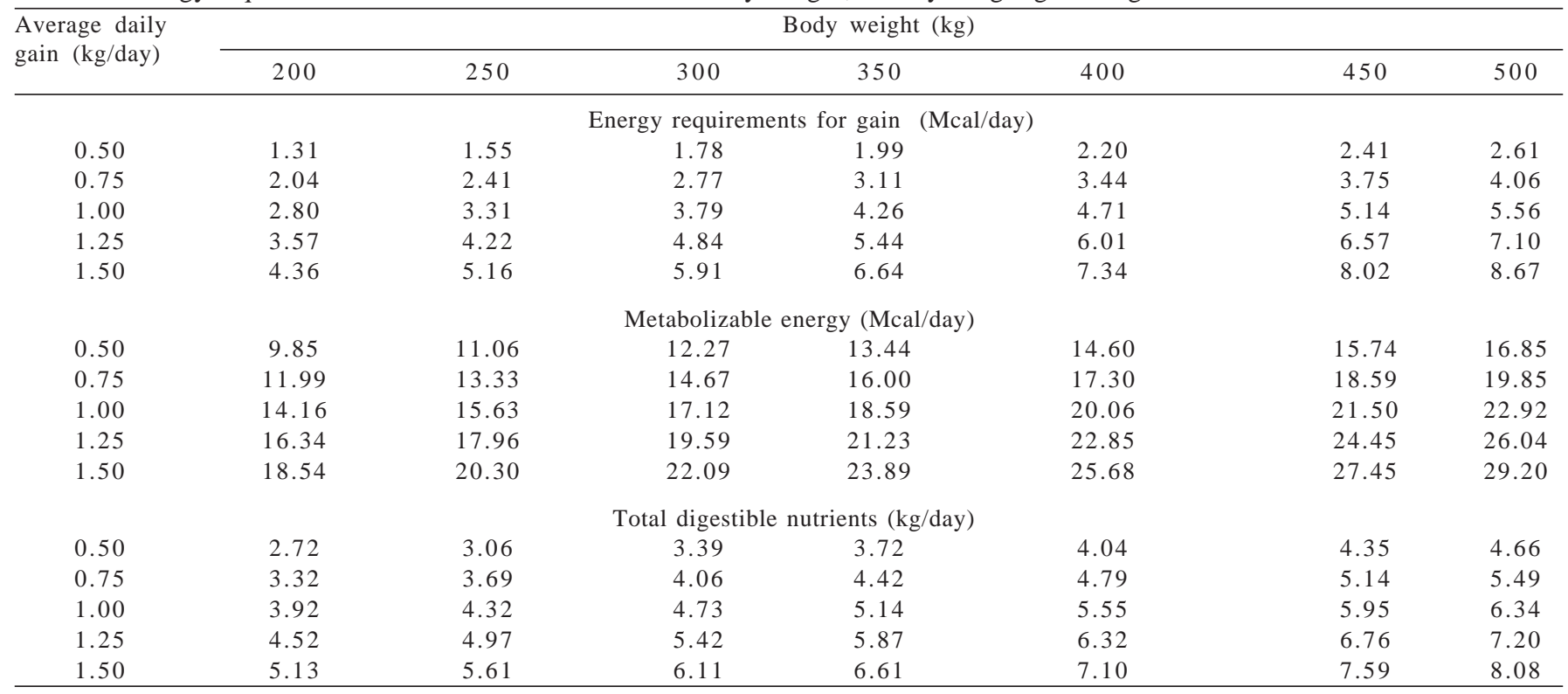

Table 5 - Protein requirements of Nellore bulls of different body weight, for any weight gain range

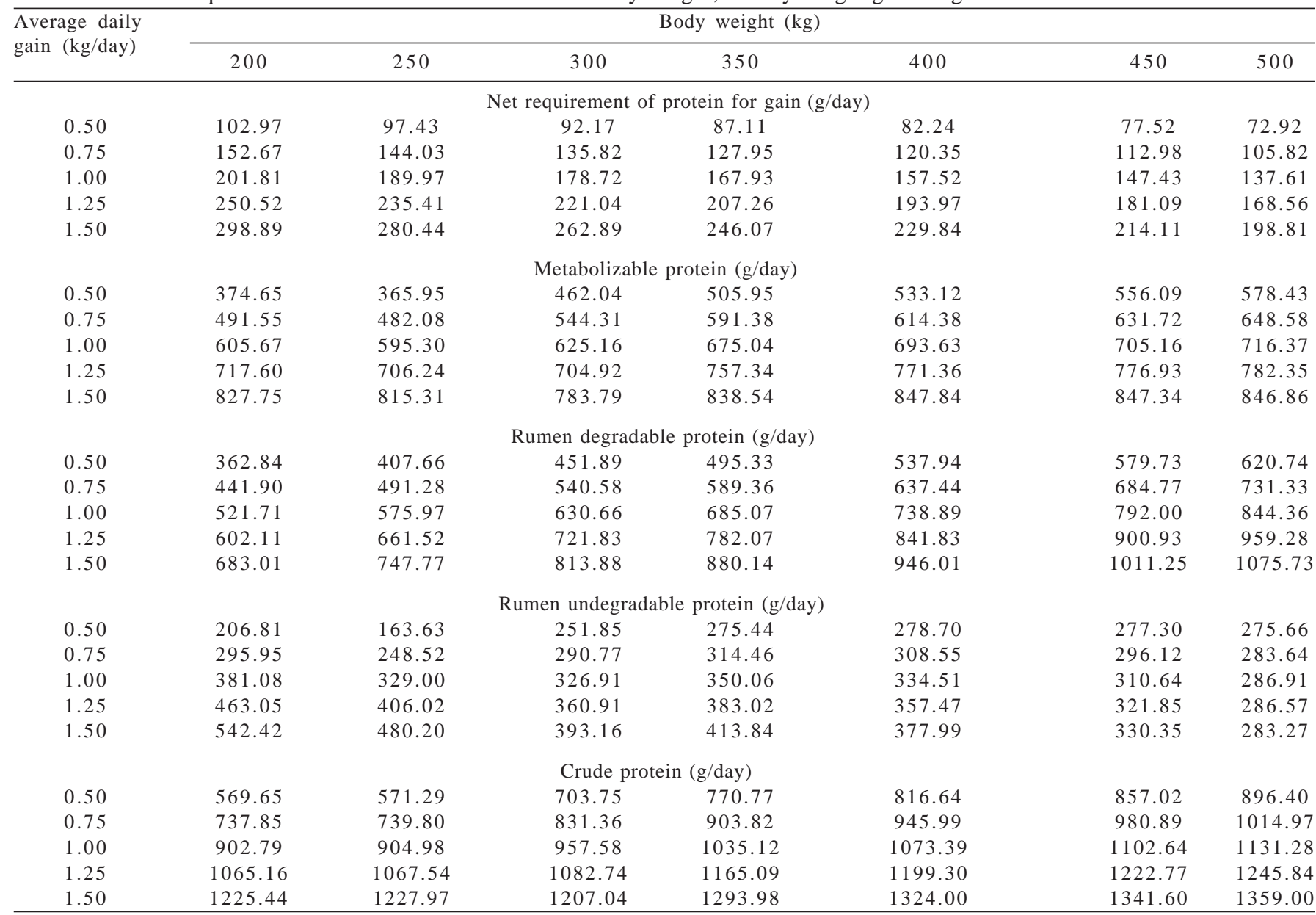


of total digestible nutrients and crude protein, which corroborate the reports by Valadares Filho et al. (2010). However, net requirements of protein for gain reduce as the animal has its weight increased. This is due to the dilution effect and to the decrease in protein deposition as the animal grows.

\section{Conclusions}

The requirements of total digestible nutrients and crude protein increase as the body weight of the animal increases as well. However, the opposite occurs with net requirements of protein for gain. Requirements of net energy and metabolizable energy for the maintenance of Nellore bulls are $76.5 \mathrm{kcal} / \mathrm{EBW}^{0.75} / \mathrm{day}$ and $113.84 \mathrm{kcal} / \mathrm{EBW}^{0.75} / \mathrm{day}$, respectively. The requirements of net energy for gain can be obtained by the equation $\mathrm{NE}_{\mathrm{g}}(\mathrm{Mcal} /$ day $)=0.0555 \times$ $\mathrm{EBW}^{0.75} \times \mathrm{EBG}^{1.095}$. Net requirements of protein for gain can be obtained by the equation RP (g/day) $=263.37 \times$ EBG $23.21 \times \mathrm{RE}$.

\section{References}

AGRICULTURAL AND FOOD RESEARCH COUNCIL - AFRC. Energy and protein requirements of ruminants. Wallingford: CAB International, 1993. 159p.

AGRICULTURAL RESEARCH COUNCIL - ARC. The nutrient requirements of ruminant livestock. London: Agricultural Research Council; The Gresham Press, 1980. 351p.

BLAXTER, K.L.; CLAPPERTON, J.L.; WAINMAN, F.W. Utilization of the energy and protein of the same diets by cattle of differents ages. Journal of Agricultural Science, v.67, n.1, p.67-75, 1966.

COELHO DA SILVA, J.F.; LEÃO, M.I. Fundamentos de nutrição de ruminantes. Piracicaba: Livroceres, 1979. 380p.

COMMONWEALTH SCIENTIFIC AND INDUSTRIAL RESEARCH ORGANIZATION - CSIRO. Nutrients requirements of domesticated ruminants. Collingwood, VIC: Commonwealth Scientific and Industrial Research Organization, 2007. 270p.

CHIZZOTTI, M.L.; VALADARES FILHO, S.C.; TEDESCHI, L.O. et al. Energy and protein requirements for growth and maintenance of F1 Nellore x Red Angus bulls, steers, and heifers. Journal of Animal Science, v.85, n.8, p.1971-1981, 2007.

CHIZZOTTI, M.L.; TEDESCHI, L.O.; VALADARES FILHO, S.C. A meta-analysis of energy and protein requirements for maintenance and growth of Nellore cattle. Journal of Animal Science. v.86, n.7, p.1588-1597, 2008.

DETMANN, E.; VALADARES FILHO, S.C. On the estimation of non-fibrous carbohydrates in feeds and diets. Arquivo Brasileiro de Medicina Veterinária e Zootecnia, v.62, n.4, p.980-984, 2010.

GARRETT, W.N. Factors influencing energetic efficiency of beef production. Journal of Animal Science, v.51, n.6, p.1434-1440, 1980.

GIONBELLI, M.P. Desempenho produtivo e exigências nutricionais de fêmeas Nelore em crescimento. 2010. 101f. Dissertação (Mestrado em Zootecnia) - Universidade Federal de Viçosa, Viçosa, MG.

HANKINS, O.G.; HOWE, P.E. Estimation of the composition of beef carcasses and cuts. [T.B.]: United States Department of Agriculture, 1946. p.1-19 (Technical Bulletin - USDA, 926).
JOHNSON, D.E.; LARSON, E.M.; JAROSZ, M.J. Extrapoling from ME to NE: unintended consequences. In: ENERGY METABOLISM OF FARM ANIMALS, 14., 1977, Newcastle. Proceedings... Newcastle: CAB International, 1977. p.383-386.

MARCONDES, M.I.; VALADARES FILHO, S.C. et al. Exigências de proteína para ganho e eficiência de conversão das exigências líquidas de proteína em exigências de proteína metabolizável de bovinos Nelore de três classes sexuais In: REUNIÃO ANUAL DA SOCIEDADE BRASILEIRA DE ZOOTECNIA, 44., 2007, Jaboticabal. Anais... Jaboticabal: Sociedade Brasileira de Zootecnia, 2007. (CD-ROM).

MARCONDES, M.I.; VALADARES FILHO, S.C., PAULINO, P.V.R. et al. Exigências nutricionais de proteína, energia e macrominerais de bovinos Nelore de três classes sexuais. Revista Brasileira de Zootecnia, v.38, n.8, p.1587-1596, 2009.

MARCONDES, M.I.; TEDESCHI, L.O.; VALADARES FILHO, S.C. Prediction of partial efficiency of use of metabolizable energy to net energy for gain. In: Southern Section of American Society of Animal Science, 2010, Orlando. Anais... Orlando: American Society of Animal Science, 2010. p.28.

NATIONAL RESEARCH COUNCIL - NRC. Nutrient requirements of beef cattle. 7.ed. Washington, D.C.: National Academy Press, 2000. 242p.

NATIONAL RESEARCH COUNCIL - NRC. Nutrient requirements of dairy cattle. 7.ed. Washington, D.C.: National Academy Press, 2001. 381p.

POCZOPKO, P. Metabolic levels in adults homeotems. ACTA Theriologica, v.16, n.1, p.1-21, 1971.

PRESTON, R.L. Feed composition tables. Beef Magazine, v.42, n.7, p.50-67, 2006.

SILVA, D.J.; QUEIROZ, A.C. Análise de alimentos (métodos químicos e biológicos). 3.ed. Viçosa, MG: Imprensa Universitária - Universidade Federal de Viçosa, 2002. 165p.

SOUZA, E.J.O.; VALADARES FILHO, S.C.; GUIM, A. et al. Exigências líquidas de proteína e energia de fêmeas Nelore, F1 Nelore X Angus, e F1 Nelore X Simental. In: CONGRESSO BRASILEIRO DE ZOOTECNIA - ZOOTEC 2009, Águas de Lindóia. Anais... Águas de Lindóia: Associação Brasileira dos Zootecnistas, 2009. (CD-ROOM).

UNDERSANDER, D.; MERTENS, D.R.; THIEX, N. [1993]. Forage analyses procedures. Omaha: National Forage Testing Association, 1993. 135p. Available at: <http://www.foragetesting. org/lab_procedure/labpro.pdf>. Accessed on: Oct. 10, 2009.

TEDESCHI, L.O.; BOIN, C.; FOX, D.G. Energy requirements for maintenance and growth of Nellore bulls and steers fed highforage diets. Journal of Animal Science, v.80, n.6, p.1671-1682, 2002.

TEDESCHI, L.O.; FOX, D.G.; GUIROY, P.J. A decision support system to improve individual cattle management. 1. A mechanistic, dynamic model for animal growth. Agricultural Systems, v.79, n.2, p.171-204, 2004.

VALADARES FILHO, S.C.; PAULINO, P.V.R.; MAGALHÃES, K.A. Exigências nutricionais de zebuínos e tabelas de composição de alimentos - BR CORTE. Viçosa, MG: UFV, Suprema Gráfica Ltda. 2006. 142p.

VALADARES FILHO, S.C.; MARCONDES, M.I.; PAULINO, P.V.R. et al. Exigências nutricionais de zebuínos puros e cruzados BR CORTE. 2.ed. Viçosa, MG: UFV, Suprema Gráfica Ltda. 2010. 193p.

VALADARES FILHO, S.C.; CHIZZOTTI, M.L. Exigências nutricionais de bovinos de corte. In: PIRES, A.V. (Ed.) Bovinocultura de corte. Piracicaba, 2011. p.203-216.

VAN SOEST, P.J.; ROBERTSON, J.B.; LEWIS, B.A. Methods for dietary fiber, neutral detergent fiber, and nonstarch polysaccharides in relation to animal nutrition. Journal of Animal Science, v.74, n.10, p.3583-3597, 1991.

WILLIAMS, C.B.; JENKINS, T.G. A dinamic model of metabolizable energy utilization in growing and mature cattle. I. Model evaluation. Journal of Animal Science, v.81, p.1390-1398, 2003. 